\title{
PENGARUH ETOS KERJA ISLAMI DAN GAYA KEPEMIMPINAN TERHADAP KINERJA KARYAWAN RUMAH MAKAN AYAM LEPAAS LHOKSEUMAWE
}

\author{
Harjoni Desky \\ Sekolah Tinggi Agama Islam Negeri (STAIN) Malikussaleh Lhokseumawe \\ barjonidesky@yaboo.com
}

\begin{abstract}
The purpose of this study is to analyze and explain the significant influence of Islamic work ethic with employee performance.This study uses a quantitative approach. The type of this research is exploratory research study. The sampling technique in this study using census method. The technique used for conducting this research through documentation, interviews, and questionnaires. This research was done by using the census of 65 employees eating spicy chicken in Lhokseumawe. Data were collected through questionnaires, interviews and documentation further processed using descriptive analysis and Path. The results of the analysis show that: (1) Islamic work ethic and a significant positive effect on employee performance, (2) transformational leadership style and a significant positive effect on employee performance.
\end{abstract}

Keywords: Islamic Work Ethics, Leadership Style, Ayam Lepaas

\begin{abstract}
Abstrak
Tujuan penelitian ini adalah untuk menganalisis dan menjelaskan pengarub signifikan antara etos kerja islami dengan kinerja karyawan. Penelitian ini menggunakan pendekatan kuantitatif. Adapaun jenis penelitian ini adalah penelitian Eksplanasi (Explanatory research). Teknikpengambilan sampel pada penelitian ini dengan menggunakan metode sensus. Teknik yang digunakan penulis dalam melakukan pengumpulan data pada penelitian ini adalab melalui dokumentasi, wawancara, dan Kuesioner. Penelitian ini dilakukan dengan teknik. sensus terhadap 65 karyawan rumah makan ayam pedas di Kota Lhokseumawe. Data dikumpulkan melalui kuesioner, wawancara dan dokumentasi selanjutnya diolah dengan menggunakan analisa diskriptif dan Path. Hasil analisis menunjukan bahwa: (1) etos kerja islami berpengarub positif dan signifikan terbadap kinerja karyawan, (2 gaya kepemimpinan transformasional berpengaruh positif dan signifikan terhadap kinerja karyawan.
\end{abstract}

Kata Kunci: Etos Kerja Islami, Gaya Kepemimpinan, Ayam Lepaas. 


\section{Pendahuluan}

Keberhasilan suatu perubahan baik besar maupun kecil bukan semata-mata ditentukan oleh sumber daya alam yang tersedia, akan tetapi banyak ditentukan oleh kualitas sumber daya manusia yang berperan merencanakan, melaksanakan, dan mengendalikan organisasi (Manullang, 2005:17). Manajemen sumber daya manusia yang dilaksanakan dengan baik akan memberikan kontribusi yang cukup besar dalam usaha mencapai sasaran organisasi atau perusahaan (Trito, 2005:32).

Pendekatan dalam upaya peningkatan kualitas sumberdaya manusia dapat dilakukan melalui pendekatan psikologi dan organisasi, budaya serta agama. Menurut Mangkunegara (2005: 4) bahwa dalam hubungannya dengan pencapaian kerja individu dan organisasi di era globalisasi perlu dilandaskan pada pendekatan psikologi dan organisasi, pendekatan budaya serta agama. Ali dan Owaihan (2008:23) berpendapat bahwa sejak diterbitkatnya penelitian oleh Max Weber pada tahun 1958 yang berjudul The Protestant Work Ethic and the Spirit of Capitalism (Etos Kerja Protestan dan Semangat Kapitalisme), perhatian para peneliti mengenai penerapkan etos kerja dan peran agama dalam memajukan pertumbuhan ekonomi dan jumlah kekayaan semakin besar.

Weber (1958) dalam Ali dan Owaihan (2008) berpendapat bahwa pimpinan perlu menerapkan etos kerja protestan dalam pengelolaan bisnis, sebagaimana etos kerja protestan merupakan kunci keberhasilan bagi pembangunan ekonomi pada masyarakat kapitalis dan Amerika. Menurut Ali dan Owaihan (2008) Sejak awal masa Islam, khususnya umat muslim telah menawarkan pandangan pada pekerjaan dan telah merumuskan secara jelas mengenai konsep etos kerja. Dimana konsep etos kerja yang dimaksud adalah etos kerja islami (Islamic work ethics) yang berlandaskan dari Al Qur'an dan ucapanucapan serta contoh dari Nabi Muhammad SAW. Adapun pengertian etos kerja islami adalah karakter dan kebiasaan manusia berkenaan dengan kerja, terpancar dari sistem keimanan/aqidah Islam yang merupakan sikap hidup mendasar terhadapnya (Asifudin, 2004:234). 
Karyawan yang memiliki etos kerja islami dalam pekerjaannya mampu meningkatkan komitmen organisasional mereka, seperti penelitian yang dilakukan oleh Yushak, et al., (2011), Yousef (2000) dan Sulistyo (2010) bahwa variabel Etos kerja secara langsung dan positif mempengaruhi komitmen organisasional. Selain mampu meningkatkan komitmen organisasional, karyawan yang memiliki etos kerja islami di dalam tempat mereka bekerja maka kinerja karyawan tersebut akan meningkat.

Penelitian yang dilakukan oleh Baddu (2007) dan Sutono dan Budiman (2009) menyatakan bahwa variable etos kerja islam berpengaruh signifikan terhadap kinerja karyawan. Selain etos kerja islami yang dimiliki oleh karyawan, peran pemimpin dalam memimpin organisasi untuk meningkatkan kinerja karyawan juga sangat berperan dalam mewujudkan tujuan perusahaan. Menurut Siagan (2009) kemampuan dan keterampilan seseorang dalam menduduki jabatan sebagai pemimpin satuan kerja dapat mempengaruhi perilaku dengan memotivasi orang lain terutama bawahannya untuk berfikir dan bertindak agar dapat mencapai kinerja karyawan sesuai dengan tujuan yang telah ditetapkan.

Menurut Hartanto (2009:512) gaya kepemimpinan sebagai suatu cara untuk memengaruhi orang lain sedemikian sehingga mereka mau dan rela memunculkan kebijakan dan kapabilitas terbaiknya di dalam proses penciptaan nilai. Luthans (2006:653) menyatakan bahwa gaya kepemiminan tertentu akan membawa keadaan menuju kinerja tinggi pada organisasi yang menghadapi tuntutan pembaharuan dan perubahan. Menurut Mulianto (2006:43) salah satu gaya kepemimpinan transformasional dinilai mampu untuk terus menerus meningkatkan daya saing organisasi/ perusahaan dalam dunia yang makin kompetitif.

Beberapa pendapat dari pakar tersebut dapat disimpulkan bahwa gaya kepemimpinan yang baik dan memotivasi orang lain terutama bawahannya untuk berfikir dan bertindak agar dapat mencapai kinerja karyawan sesuai dengan tujuan yang telah ditetapkan mampu menciptakan karyawan untuk senantiasa berkinerja tinggi dan mampu membawa perusahaan kearah yang lebih baik dalam menghadapi dunia yang semakin kompetitif. Gaya 
kepemimpinan tersebut memberikan pengaruh yang signifikan terhadap komitmen karyawan.

Rumah makan Ayam Lepaas adalah rumah makan yang menjual makanan berupa aneka menu ayam dan minuman. Pendirinya adalah Suparno. Lelaki yang tumbuh besar di Simpang Keuramat Kabupaten Aceh Utara. Gerai pertama Ayam Lepaas didirikan Suparno awal November 2009 silam. Gerai pertama itu dibuka di kawasan Lampriek, Banda Aceh, tepatnya di depan SMA 3. Dari sinilah, awal mula Suparno mulai mengembangkan usaha kulinernya.

Hingga sekarang, dalam umurnya yang belum sampai tiga tahun, Ayam Lepaas Suparno telah memiliki 43 outlet di seluruh Indonesia, dan menampung ratusan pekerja. Yang paling banyak adalah di wilayah Jabodetabek dengan 23 outlet. Sedangkan di Aceh sendiri berjumlah 11 outlet. Selebihnya tersebar di kota-kota lain di Indonesia. Dan outlet yang paling terakhir dibangun adalah di kota Jambi pada awal Mei 2012. Saat ini usaha Ayam Lepaas sudah bekerjasama dengan 200 orang mitra dan sudah bisa menampung 1000 lebih karyawan serta sekitar 250 karyawan berada di Aceh.

Rumah Makan Ayam Lepaas ini menerapkan spiritual company yang terdiri dari dakwah dan pendidikan islam. Untuk dakwah dilakukan melalui olah raga, kegiatan sosial, infaq karyawan dan seni budaya. Sedangkan untuk pendidikan islamnya yakni pengadaan tausiyah rutin di oulet-outlet dan kantor, bulletin bulanan, dan belajar membaca al-Qur'an. Berdasarkan latar belakang masalah di atas, maka penelitian ini akan mengkaji pengaruh etos kerja islami dan gaya kepemimpinan terhadap kinerja karyawan pada rumah makan Ayam Lepas di Kota Lhokseumawe.

\section{Relasi antara Agama dan Etos Kerja}

Secara teoritis, pengkajian dan penelitian tentang hubungan agama dan etos kerja ini melahirkan satu teori ilmu besar (grand theory) yang disebut teori fungsional. Teori ini berpandangan bahwa fungsi agama adala mendukung dan melestarikan masyarakat yang sudah ada. karena itu, agama bersifat fungsional terhadap persatuan dan 
solidaritas sosial (Betty R. Scharf, 1995:93). Salah satu tokoh besar dari aliran ini adalah Max Weber. Dalam buku mognum opusnya yang berjudul The Protestant Ethic and the Spirit of Capitalism, dia menyatakan adanya korelasi positif antara agama Kristen Protestan dengan etos kerja dalam membangun dan mengembangkan kapitalisme.

Teori ini kemudian diuraikan secara lebih mendetail dalam karya Taufiq Abdullah (ed), Agama, Etos Kerja dan Perkembangan Ekonomi (Jakarta: LP3ES, 1979). Buku yang membuat beberapa tulisan dari sejumlah penulis yang berbeda luar maupun dalam negeri, memberikan gambaran secara lengkap mengenai pemikiran dan kerangka teoritis Max Weber mengenai teori fungsional. Di antara mereka adalah Taufiq Abdullah, "Tesis Weber dan Islam di Indonesia; Max Weber, "Sekte-Sekte Protestan dan Semangat Kapitalisme; Max Weber, "Sikap Agama-Agama Dunia Lain terhadap Orde Sosial dan Ekonomi"; Bryan S.Turner, "Islam, Kapitalisme dan Tesis Weber": dan Husein Alatas, "Tesis Weber di Asia Tenggara". Selain itu, untuk memperkuat aspek teoritis mengenai relasi agama dan etos kerja, buku ini juga membuat tulisan Clifford Geertz, dengan judul "Perubahan Sosial dan Modernisasi Ekonomi di Dua Kota Indonesia". Kumpulan tulisan yang terdapat dalam buku tersebut selain banyak memberikan landasan pemikiran, juga mengkritisi teori weber sebagai salah satu alternatf pemikiran yang bisa dijadikan landasan penerapannya di agama-agama lain.

Penggunaan asumsi yang sama mengenai relasi agama dan etos kerja, Muhammad Tholchah Hasan melalui karyanya Dinamika Kebidupan Religius, menggembangkan kajian Islam etos kerja dari perspektif tasawuf. Dalam kajian tasawuf, posisi manusia terhadap kerja dapat dibagi ke dalam dua kategori. Pertama, orang yang berada di maqam tajrid, yakni orang-orang yang posisinya sudah tidak lagi membutuhkan kerja. Ini terjadi karena beberapa faktor, seperti sudah lanjut usia, terlalu kecil melakukan pekerjaan, atau mungkin orang tersebut telah memiliki satu tingkat tertentu dalam hidupnya sehingga tidak menginginkan berbagai kesenangan yang mengharuskannya kerja. 
Kategori kedua, orang yang berada pada maqam ikhtiyar, yakni mereka yang masih membutuhkan kerja karena masih memerlukan rumah, kendaraan dan kebutuhan-kebutuhan lainnya. Dalam konteks ini, Tholchah Hasan melakukan kontekstualisasi kategori maqam ikhtiyar untuk mengembangkan etos kerja dalam Islam. (Hasan, 2000:184-196). Sedangkan kajian secara politis mengenai hubungan agama dan etos kerja sebagai pilihan politik kebijakan pemerintah terungkap dalam tulisan Yahya Muhaimin, "Islam dan Etos Kerja: Tinjauan Politik". Dalam pandangannya, sebagai negara berpenduduk mayoritas Muslim, sudah sepantasnya apabila di masa mendatang pemerintah Indonesia mulai membuat policy untuk mengambil dan mengembangkan nilai-nilai yang terkandung dalam ajaran-ajaran Islam sebagai spirit pembangunan bangsa. Hal ini dianggap penting dan signifikan untuk transformasikan agama ke dalam aspek kehidupan sosial.

Pandangan demikian didukung oleh tulisan Prijono Tjiptoherijanto, Etos Kerja dan Moral Pembangunan dalam Islam (1998). Ideologi pembangunanisme (developmentalism) yang cenderung positivisme yang selama ini dijadikan sebagai sandaran pembangunan bangsa Indonesia, telah melahirkan alienasi dan degradasi agama dari wilayah-wilayah yang bersifat sosial. Kuatnya ideologi ini telah menyingkirkan agama hanya berkenaan dengan persoalan ritualistik formalistik semata. Karenanya, fungsi sosial agamapun selama dua dekade termarjinalkan dalam kehidupan nyata. Untuk itu, sebagai aset dan "budaya" bangsa sebenarnya agama memiliki peran signifikan dalam pembangunan bangsa ini.

Melalui nilai-nilai humanis, keadilan sosial, tanggung jawab, amanah, dan sebagainya yang terkandung di dalam agama Islam, sebagai contoh, pemerintah bisa mengembangkannya sebagai budaya etos kerja bangsa. Kenyataan ini diperkuat oleh buku Prof. Dr. KH.Ali Yafie dkk, Fiqih Perdagangan Bebesa, yang mengungkapkan "ekonomi pembangunan" di Indonesia telah melahirkan permasalahan-permasalahan yang tidak diantisipasi, seperti inflasi, beban utang dan kesulitan dalam perencanaan. (Ali Yafie, dkk, 2003: 82).

Sementara dalam kerangka aplikatif dari teori Weber ini, tulisan M. Bambang Pranowo, "Tarekat dan Perilaku Ekonomi" 
(1992), memberikan sejumlah kerangka pemikiran mengenai perilaku ekonomi di kalangan pengikut tarekat. Dalam pandangannya, perilaku perekonomian yang menjunjung tinggi ketekunan, kegigihan, mentalitas usaha yang tinggi memiliki korelasi yang positif dengan ajaran-ajaran yang terdapat di dalam tarekat tertentu. Penelitiannya membuktikan aliran tarekat sebagai spirit dalam meningkatkan aktivitas dan kegiatan perekonomian. Selain itu, dengan menggunakan teori Weber, Suging Sugiyono dkk, berusaha mengaplikasikan dalam satu penelitian tentang Etos Kerja Wanita Bakul di Kotamadia Yogyakarta dan Kabupaten Sleman. (Sugeng Sugiyono, 1993: 3). Penelitian ini berusaha mengaplikasikan grand theory Weber dalam konteks pedagang bakul dengan menghubungkan anatar kualitas keagamaan pedagang dengan kegiatan bisnis bakul.

\section{Gaya Kepemimpinan dan Kinerja}

Kepemimpinan menurut didefinisikan sebagai sarana pencapaian tujuan yang dimaksudkan dalam hubungan ini pemimpin merupakan seseorang yang memiliki suatu program dan yang berperilaku secara bersama-sama dengan anggota-anggota kelompok dengan mempergunakan cara atau gaya tertentu, sehingga kepemimpinan mempunyai peranan sebagai kekuatan dinamik yang mendorong, memotivasi dan mengkoordinasikan organisasi dalam mencapai tujuan yang telah ditetapkan. Dalam kepemimpinan seseorang juga memiliki ciri sendiri atau gaya kepemimpinan yang khas (Stogdill dalam Wahjosumidjo 1994:23). Gaya kepemimpinan secara sederhana dapat didefenisikan adalah perilaku dan strategi, sebagai hasil kombinasi dari falsafah, ketrampilan, sifat, sikap, yang sering diterapkan sorang pimpinan ketika ia mencoba mempengaruhi kinerja bawahannya (Tampubolon, 2007). Faktor-faktor penting yang terdapat dalam pengertian kepemimpinan yaitu : 1) Pendayagunaan pengaruh, 2) Hubungan antar manusia, 3) Proses komunikasi, dan 4) Pencapaian suatu tujuan. Kepemimpinan tergantung pada kuatnya pengaruh yang diberikan serta intesitas hubungan antara pemimpin dengan pengikut (Rivai, 2006). 


\section{Jenis-jenis Gaya Kepemimpinan}

Menurut Siagian (2008), ada tiga macam gaya kepemimpinan yang telah dikenal secara luas, yaitu :

1. Demokratis, yaitu gaya kepemimpinan yang mengarah pada pengambilan keputusan sebagai keputusan bersama dan seluruh anggota system sosial yang bersangkutan.

2. Otokrasi, yaitu kepemimpinan yang mengarah pada pengambilan keputusan tergantung kepada pemimpinnya sendiri.

3. Laissez Faire, yaitu gaya kepemimpinan yang menyerahkan pengambilan keputusan kepada masing-masing anggota sistem sosial itu sendiri.

Gaya kepemimpinan yang ada dalam suatu kelompok atau masyarakat tergantung pada situasi yang terdapat pada kelompok masyarakat tersebut. Dalam situasi yang menguntungkan cenderung gaya kepemimpinan bersifat otoriter. Pada situasi dimana hubungan antara angota dengan pemimpinnya sedang-sedang saja atau anggota kelompok sangat dipentingkan, maka gaya kepemimpinan lebih diarahkan pada gaya kepemimpinan yang demokratis.

House dan Mitchel (Sutarto 1995:131) disamping mengemukakan adanya dua faktor yang mempengaruhi perilaku kepemimpinan, yaitu faktor pribadi bawahan dan faktor lingkungan kerja, kedua orang tersebut membedakan adanya empat gaya kepemimpinan, yaitu: Pemimpin Pengarah (Leader Directiveness); Pemimpin Pendukung (Leader Supportiveness); Pemimpin Peranserta (Participative Leadership); dan Kepemimpinan Berorientasi Prestasi (Achievement-Oriented Leadership).

Keberhasilan suatu organisasi dipengaruhi oleh kinerja (job performance) sumber daya manusia, untuk itu setiap perusahaan akan berusaha untuk meningkatkan kinerja pegawai dalam mencapai tujuan organisasi yang telah ditetapkan. Budaya organisasi yang tumbuh dan terpelihara dengan baik akan mampu memacu organisasi ke arah perkembangan yang lebih baik. Disisi lain, kemampuan pemimpin dalam menggerakkan dan memberdayakankan pegawainya akan mempengaruhi kinerja. Istilah kinerja dari kata job performance atau actual performance (prestasi kerja atau 
prestasi sesungguhnya yang dicapai oleh seseorang). Prestasi kerja pada umumnya dipengaruhi oleh kecakapan, keterampilan, pengalaman dan kesungguhan kerja dari tenaga kerja yang bersangkutan.

Secara etimologi, kinerja berasal dari kata prestasi kerja (performance). Sebagaimana dikemukan oleh Mangkunegara (2007) bahwa isitilah kinerja dari kata kata job performance atau actual performance (prestasi kerja atau prestasi sesungguhnya yang dicapai oleh seseorang) yaitu hasil kerja secara kualitas dan kuantitas yang dicapai oleh seorang pegawai dalam melaksanakan tugasnya sesuai dengan tanggung jawab yang diberikan padanya. Lebih lanjut Mangkunegara (2007) menyatakan bahwa pada umumnya kinerja dibedakan menjadi dua, yaitu kinerja individu dan kinerja organisasi. Nawawi (2004) menyatakan bahwa, "Kinerja adalah hasil pelaksanaan suatu pekerjaan, baik bersifat fisik/ material maupun non fisik/ non material.

Menurut Simanjutak (2005),"Kinerja adalah tingkatan pencapaian hasil atas pelaksanaan tugas tertentu. Simanjuntak juga mengartikan kinerja individu sebagai tingkat pencapaian atau hasil kerja seseorang dari sasaran yang harus dicapai atau tugas yang harus dilaksanakan dalam kurun waktu tertentu". Foster dan Seeker (2001) menyatakan bahwa, "Kinerja adalah hasil yang dicapai seseorang menurut ukuran yang berlaku untuk pekerjaan yang bersangkutan".

Kinerja individu adalah hasil kerja pegawai baik dari segi kualitas maupun kuantitas berdasarkan standar kerja yang telah ditentukan, sedangkan kinerja organisasi adalah gabungan dari kinerja individu dan kinerja kelompok.

\section{Indikator Kinerja}

Ukuran secara kualitatif dan kuantitatif yang menunjukkan tingkatan pencapaian suatu sasaran atau tujuan yang telah ditetapkan adalah merupakan sesuatu yang dapat dihitung serta digunakan sebagai dasar untuk menilai atau melihat bahwa kinerja setiap hari dalam perusahaan dan perseorangan terus mengalami peningkatan sesuai dengan rencana yang telah ditetapkan. 
Menurut Mathis dan Jackson (2002) kinerja pegawai adalah mempengaruhi seberapa banyak kontribusi kepada organisasi antara lain termasuk:

1. Kuantitas Kerja

Standar ini dilakukan dengan cara membandingkan antara besarnya volume kerja yang seharusnya (standar kerja norma) dengan kemampuan sebenarnya.

2. Kualitas Kerja

tandar ini menekankan pada mutu kerja yang dihasilkan dibandingkan volume kerja.

3. Pemanfaatan Waktu

Yaitu penggunaan masa kerja yang disesuaikan dengan kebijaksanaan perusahaan.

4. Tingkat Kehadiran

Asumsi yang digunakan dalam standar ini adalah jika kehadiran pegawai di bawah standar kerja yang ditetapkan maka pegawai tersebut tidak akan mampu memberikan kontribusi yang optimal bagi perusahaan .

5. Kerjasama

Keterlibatan seluruh pegawai dalam mencapai target yang ditetapkan akan mempengaruhi keberhasilan bagian yang diawasi. Kerjasama antara pegawai dapat ditingkatkan apabila pimpinan mampu memotivasi pegawai dengan baik.

Sementara itu, indikator kinerja karyawan menurut Guritno dan Waridin (2005) adalah sebagai berikut :

1. Mampu meningkatkan target pekerjaan.

2. Mampu menyelesaikan pekerjaan tepat waktu.

3. Mampu menciptakan inovasi dalam menyelesaikan pekerjaan.

4. Mampu menciptakan kreativitas dalam menyelesaikan pekerjaan.

5. Mampu meminimalkan kesalahan pekerjaan.

Berdasarkan keseluruhan definisi diatas dapat dilihat bahwa kinerja pegawai merupakan output dari penggabungan faktor-faktor yang penting yakni kemampuan dan minat, penerimaan seorang 
pekerja atas penjelasan delegasi tugas dan peran serta tingkat motivasi seorang pekerja. Semakin tinggi faktor-faktor diatas, maka semakin besarlah kinerja karyawan yang bersangkutan.

\section{Faktor-faktor yang mempengaruhi kinerja}

Menurut Sedarmayanti (2007), faktor-faktor yang mempengaruhi kinerja antara lain :1) Sikap dan mental (motivasi kerja, disiplin kerja, dan etika kerja), 2) Pendidikan, 3) Keterampilan, 4) Manajemen kepemimpinan, 5) Tingkat penghasilan, 6) Gaji dan kesehatan, 7) Jaminan sosial, 8) Iklim kerja, 9) Sarana dan prasarana, 10) Teknologi, dan 11) Kesempatan berprestasi.

Menurut Mathis dan Jackson (2002) dalam pembahasan mengenai permasalahan kinerja karyawan maka tidak terlepas dari berbagai macam faktor yang menyertai diantaranya :

1. Faktor kemampuan (ability)

Secara psikologis kemampuan (ability) pegawai terdiri dari kemampuan potensi (IQ) dan kemampuan reality (knowledge dan skill) artinya pegawai yang memiliki IQ diatas rata-rata (110120) dengan pendidikan yang memadai untuk jabatannya dan terampil dalam mengerjakan pekerjaan sehari-hari maka akan lebih mudah mencapai kinerja diharapkan. Oleh karena itu pegawai perlu ditempatkan pada pekerjaan yang sesuai dengan keahliannya.

2. Faktor motivasi

Motivasi terbentuk sikap (attitude) seorang pegawai dalam menghadapi situasi (situation) kerja. Motivasi merupakan kondisi yang menggerakkan diri pegawai yang terarah untuk mencapai tujuan kerja.

Menurut Sedarmayanti (2007), instrumen pengukuran kinerja merupakan alat yang dipakai dalam mengukur kinerja individu seorang pegawai yang meliputi, yaitu :

1. Prestasi Kerja, hasil kerja pegawai dalam menjalankan tugas, baik secara kualitas maupun kuantitas kerja.

2. Keahlian, tingkat kemampuan teknis yang dimiliki oleh pegawai dalam menjalankan tugas yang dibebankan kepadanya. 
Keahlian ini bisa dalam bentuk kerjasama, komunikasi, insentif, dan lain-lain.

3. Perilaku, sikap dan tingkah laku pegawai yang melekat pada dirinya dan dibawa dalam melaksanakan tugas-tugasnya. Pengertian perilaku disini juga mencakup kejujuran, tanggung jawab dan disiplin.

4. Kepemimpinan, merupakan aspek kemampuan manajerial dan seni dalam memberikan pengaruh kepada orang lain untuk mengkoordinasikan pekerjaan secara tepat dan cepat, termasuk pengambilan keputusan, dan penentuan prioritas.

Hasil penelitian Baek-Kyoo (Brian) Joo, et, al (2012) dan Desianty (2005) menyatakan bahwa kepemimpinan transformasional berpengaruh positif terhadap komitmen. Daft (2011:349) menyampaikan bahwa penelitian terbaru membenarkan bahwa gaya kepemimpinan berdampak positif terhadap pengembangan dan kinerja pengikut. Rofiudin (2008) menyatakaan bahwa variable gaya kepemimpinan yang meliputi pemberian motivasi, pengarahan pemimpin, perhatian pemimpin, mendelegasikan pekerjaan berpengaruh signifikan terhadap kinerja pegawai. Penelitian yang dilakukan oleh Sibili (2012), Khoirusmadi (2011), Pattiasina (2011) dan Suryo (2010) memberikan kesimpulan bahwa gaya kepemimpinan berpengaruh signifikan dan positif terhadap kinerja karyawan.

\section{Metode Penelitian}

Penelitian ini menggunakan pendekatan kuantitatif. Adapaun jenis penelitian ini adalah penelitian Eksplanasi (Explanatory research). Populasi dalam penelitian ini adalah jumlah karyawan pada rumah makan Ayam Lepaas di Kota Lhokseumawe yang berjumlah 65 karyawan. Teknik pengambilan sampel pada penelitian ini dengan menggunakan metode sensus. Teknik yang digunakan penulis dalam melakukan pengumpulan data pada penelitian ini adalah melalui dokumentasi, wawancara, dan Kuesioner, dimana data yang diambil dari kuisioner dengan menggunakan skala Likert. Pada penelitian ini terdapat dua variabel yaitu variabel etos kerja islami dan gaya kepemimpinan serta kinerja karyawan sebagai variabel terikat. 
Uji Instrumen dalam penelitian ini menggunakan Uji Validitas, Uji Reliabilitas, Uji Asumsi Klasik diantaranya Uji Linieritas, Uji Normalitas, Uji Heteroskedastisitas. Sedangkan untuk analisis data menggunakan Data Deskriptif dan menggunakan Analisis Jalur (Path Analysis). Menurut Solimun (2002) Langkah-langkah untuk menghitung koefisien jalur (Path Analysis) adalah sebagai berikut : Langkah pertama: Merancang model berdasarkan konsep dan teori, Langkah kedua : Periksa Asumsi, Langkah ketiga : Pendugaan parameter atau perhitungan koefisien path, Langkah keempat : pemeriksaan validitas model, Langkah kelima : interprestasi hasil analisis.

\section{Analisis}

\section{Deskripsi Jawaban Responden}

Pada analisis diskriptif akan diketahui distribusi item-item dari variabel Etos Kerja Islami (X1), Gaya Kepemimpinan (X2), dan Kinerja Karyawan (Y) secara keseluruhan yang diperoleh dari jawaban responden melalui kuesioner dalam jumlah prosentase.

Tabel 1. Deskripsi Jawaban Responden untuk Variabel Etos Kerja Islami

\begin{tabular}{lc}
\hline \multicolumn{1}{c}{ Item } & $\begin{array}{c}\text { Rata-Rata } \\
\text { Skor }\end{array}$ \\
\hline $\begin{array}{l}\text { Saya dapat menerima kenyataan berkenaan dengan diri sendiri, } \\
\text { orang lain dan keadaan alam }\end{array}$ & 4,03 \\
$\begin{array}{l}\text { Saya berperilaku secara wajar dan tidak dibuat-buat } \\
\text { Saya memiliki pendirian yang teguh dan tidak mudah }\end{array}$ & 4,26 \\
terpengaruh & 4,10 \\
$\begin{array}{l}\text { Konsentrasi perbuatan saya tidak pada ego, melainkan pada } \\
\text { kewajiban dan rasa tanggung jawab }\end{array}$ & 4,09 \\
$\begin{array}{l}\text { Saya mempunyai kehidupan motivasi, terutama digerakan oleh } \\
\text { motivasi ibadah dan hasrat memperoleh kehidupan surgawi di } \\
\text { akhirat kelak. }\end{array}$ & 4,40 \\
$\begin{array}{l}\text { Saya pernah atau sering mengalami pengalaman puncak (amat } \\
\text { dekat dengan Allah ketika melakukan kerja dalam rangka }\end{array}$ & 4,00 \\
beribadah) & \\
$\begin{array}{l}\text { Saya mampu membedakan antara tujuan benar dan salah, baik } \\
\text { dan buruk }\end{array}$ & 4,26 \\
& \\
\hline
\end{tabular}




\begin{tabular}{lc}
\hline Saya menyukai efisiensi dan efektivitas kerja & 4,21 \\
Saya mempunyai disiplin pribadi & 4,01 \\
Saya memiliki jiwa sosial dan sifat demokratis & 3,86 \\
Saya mengembangkan kreativitas & 3,82 \\
Saya percaya pada potensi karunia Allah SWT untuk & 4,58 \\
melaksanakan tugas: bertawakal hanya kepada Allah SWT & \\
Saya mengembangkan sikap hidup kritis konstruktif (disiplin, & 4,29 \\
professional, dan menjaga amanah) & \\
Rata-rata Skor Variabel & $\mathbf{4 , 1 5}$ \\
\hline
\end{tabular}

Sumber : Hasil wawancara dengan 65 karyawan rumah makan Ayam Lepas di Kota Lhokseumawe

Tabel 2. Deskripsi Jawaban Responden untuk Variabel Gaya Kepemimpinan

\begin{tabular}{|c|c|}
\hline Item & $\begin{array}{l}\text { Rata-Rata } \\
\text { Skor }\end{array}$ \\
\hline Pemimpin menyampaikan visi dan misi organisasi dengan jelas & 4,01 \\
\hline Saya merasa bangga dengan kepemimpinannya & 3,77 \\
\hline $\begin{array}{l}\text { Gaya kepemimpinan atasan saya mampu menimbulkan sikap } \\
\text { positif bawahan }\end{array}$ & 3,77 \\
\hline $\begin{array}{l}\text { Gaya kepemimpinan atasan saya mampu menimbulkan sikap } \\
\text { setia kepada perusahaan/organisasi }\end{array}$ & 3,72 \\
\hline $\begin{array}{l}\text { Gaya kepemimpinan atasan mampu menjadi inspirasi bawahan } \\
\text { dalam bekerja }\end{array}$ & 3,75 \\
\hline $\begin{array}{l}\text { Pemimpin mampu memberi petunjuk dan sasaran yang } \\
\text { mendorong bawahan sehingga mampu memikirkan masalah } \\
\text { lama dengan cara-cara baru }\end{array}$ & 3,79 \\
\hline $\begin{array}{l}\text { Pemimpin mampu mengstimulasi atau membangkitkan ide-ide } \\
\text { kepada seluruh bawahan yang menunjang keberhasilan } \\
\text { organisasi }\end{array}$ & 3,86 \\
\hline $\begin{array}{l}\text { Pemimpin mampu memberi kepada bawahan cara-cara baru } \\
\text { dalam melihat masalah yang pada awalnya keliatannya tidak } \\
\text { dapat diselesaikan }\end{array}$ & 3,83 \\
\hline Menghargai secara personal terhadap kemampuan bawahan & 3,90 \\
\hline Menghargai secara personal terhadap kemampuan bawahan & 3,92 \\
\hline Berusaha menunjukkan perhatian pada hasil & 3,94 \\
\hline Rata-rata Skor Variabel & 3,84 \\
\hline
\end{tabular}

Sumber : Hasil wawancara dengan responden 65 karyawan Ayam Lepaas 
Tabel 3. Deskripsi Jawaban Responden untuk Variabel Kinerja Karyawan

\begin{tabular}{lc}
\hline \multicolumn{1}{c}{ Item } & $\begin{array}{c}\text { Rata-Rata } \\
\text { Skor }\end{array}$ \\
\hline Saya selalu menyelesaikan pekerjaan dengan rapi & 3,75 \\
Saya selalu menyelesaikan pekerjaan dengan teliti & 3,71 \\
Saya selalu menyelesaikan pekerjaan dengan tepat waktu & 3,88 \\
Saya memiliki tanggung jawab terhadap pekerjaan yang & 4,23 \\
dilakukan & \\
Saya mampu kerjasama dengan rekan kerja & 4,22 \\
Rata-rata Skor Variabel & $\mathbf{3 , 8 3}$ \\
\hline
\end{tabular}

Sumber : Hasil wawancara dengan responden 65 karyawan Ayam Lepaas

Perhitungan Analisis Jalur

Tabel 4. Hasil Analisis Path $\mathrm{X}_{1}, \mathrm{X}_{2}$ terhadap Y

\begin{tabular}{ccccc}
\hline Variabel & Beta & t hitung & Sig t & Keterangan \\
\hline $\mathrm{X}_{1}$ & 0,281 & 2,678 & 0,009 & Signifikan \\
$\mathrm{X}_{2}$ & 0,290 & 2,349 & 0,022 & Signifikan \\
$\mathrm{t}$ Tabel & & $=1,993$ & & \\
R Square & & $=0,530$ & & \\
\hline
\end{tabular}

Sumber : Data Primer Diolah, Januari 2014

Data dari tabel 4 di atas dapat dijelaskan bahwa:

1. Variabel Etos Kerja Islami $\left(\mathrm{X}_{1}\right)$ memiliki nilai t hitung sebesar 2,678 dengan probabilitas sebesar 0,009. Karena |thitung $\mid>$ ttabel $(2,678>1,993)$ atau sig $t<5 \%(0,000<0,05)$ maka variabel $\mathrm{X}_{1}$ (Etos Kerja Islami) berpengaruh signifikan terhadap Kinerja Karyawan (Y). karena koefisien path bertanda positif $(0,281)$ mengindikasikan semakin baik Etos Kerja Islami mengakibatkan semakin meningkat pula Kinerja Karyawan.

2. Variabel Gaya Kepemimpinan (X2) memiliki nilai ${ }_{t}$ hitung sebesar 2,349 dengan probabilitas sebesar 0,022. Karena |thitung | > ttabel $(2,349>1,993)$ atau sig $t<5 \%(0,022<0,05)$ maka variabel Gaya Kepemimpinan (X2) berpengaruh signifikan terhadap Kinerja Karyawan (Y). Karena koefisien path bertanda positif 
$(0,290)$ mengindikasikan semakin baik Gaya Kepemimpinan mengakibatkan semakin meningkat pula Kinerja Karyawan.

\section{Koefisien Determinasi Total}

Untuk mengetahui apakah model dapat menjelaskan informasi yang terkandung di dalam data. Perhitungan koefisien determinasi total dari setiap variabel yang mempunyai pengaruh kausal (signifikan) ke variabel endogen. Sebagai berikut:

$$
\mathrm{R}_{\mathrm{m}}^{2}=1-(0,410 \times 0,470)=0,807 \text { atau } 80,7 \%
$$

Tabel 5. Hasil Pengujian Hipotesis Pengaruh Langsung

\begin{tabular}{ccccc}
\hline Variabel Bebas & Variabel Terikat & Path & p-value & Keterangan \\
\hline $\mathrm{X}_{1}$ & $\mathrm{Y}$ & 0,281 & 0,009 & Signifikan \\
$\mathrm{X}_{2}$ & $\mathrm{Y}$ & 0,290 & 0,022 & Signifikan \\
\hline
\end{tabular}

Sumber : Data Primer (diolah), Januari 2014

Hasil penelitian menunjukkan adanya pengaruh secara langsung antara variabel etos kerja islami terhadap kinerja karyawan pada rumah makan Ayam Lepaas di Kota Lhokseumawe. Maka semakin baik etos kerja islami yang dimiliki oleh karyawan mengakibatkan semakin meningkat pula kinerja karyawan. Beberapa faktor yang mempengaruhi terjadinya pengaruh yang siginifikan pada etos kerja Islami terhadap kinerja karyawan tersebut, disebabkan karena berdasarkan data-data yang diperoleh dilapangan diketahui bahwa karyawan selama ini bekerja berorientasi tingkat pemahaman spiritual sehingga dalam pengelolaan sumber daya manusia pada rumah makan Ayam Lepaas di Kota Lhokseumawe lebih menekankan pemahaman etos kerja islami yang didasarkan pada Al-Qur'an dan Hadits agar produktivitas kerja karyawan dapat menunjang kepuasan pelanggan, serta mempengaruhi kinerja yang ditunjukkan oleh karyawan. Hasil penelitian ini memperkuat hasil penelitian sebelumnya Baddu (2007), Sutono \& Budiman (2009), Sulityo (2010). 
Hasil penelitian menunjukkan adanya pengaruh secara langsung antara variabel gaya kepemimpinan terhadap kinerja karyawan pada rumah makan Ayam Lepaas di Kota Lhokseumawe. Maka semakin baik gaya kepemimpinan yang diterapkan oleh pemimpin pada rumah makan Ayam Lepaas di Kota Lhokseumawe maka akan mengakibatkan semakin meningkat pula kinerja karyawan. Secara empiris, hasil penelitian ini memperkuat penelitian yang dilakukan oleh Sibili (2012), Khoirusmadi (2011), Pattiasina (2011) dan Suryo (2010) memberikan kesimpulan bahwa kepemimpinan berpengaruh signifikan dan positif terhadap kinerja karyawan.

\section{Kesimpulan}

Hasil penelitian menunjukkan bahwa etos kerja islami dan gaya kepemimpinan berpengaruh positif dan signifikan terhadap kinerja karyawan pada Rumah Makan Ayam Lepaas di Kota Lhokseumawe. Nilai-nilai etos kerja islami yang dilaksanakan dengan baik oleh karyawan akan menumbuhkan komitmen yang tinggi terhadap organisasi yang pada akhirnya berdampak pada peningkatan kinerja karyawan pada Rumah Makan Ayam Lepaas di Kota Lhokseumawe. Pimpinan yang mampu menerapkan gaya kepemimpinan dengan baik akan menumbuhkan komitmen yang tinggi terhadap organisasi yang pada akhirnya berdampak pada peningkatan kinerja karyawan pada Rumah Makan Ayam Lepaas di Kota Lhokseumawe.

\section{Daftar Pustaka}

Abdullah, Taufiq. 1979. Agama, Etos Kerja dan Perkembangan Ekonomi, Jakarta: LP3ES.

Ali, Abbas J. dan Abdullah Al-Owaihan. 2008)."Islamic work ethic: a critical review", Cross Cultural Management: An International Journal, Vol. 15 Iss: 1 pp. 5 - 19 http://dx.doi.org/10.1108/ 13527600810848791

Asifudin, Ahmad. 2004. Etos Kerja Islami. Yogyakarta : UII Press.

Baddu, Irwan. 2007. Pengaruh Etos Kerja Islami Terhadap Kinerja Karyawan Studi Pada Karyawan Koperasi Baitul Maal Wat Tamwil Maslahah Mursalah Lil Ummah Sidogiri Kabupaten 
Pasuruan. Skripsi. Fakultas Ilmu Administrasi Universitas Brawijaya, Malang.

Baek-Kyoo (Brian) Joo, Hea Jun Yoon, Chang-Wook Jeung. 2012."The effects of core self-evaluations and transformational leadership on organizational commitment", Leadership \& Organization Development Journal, Vol. 33 Iss: 6 pp. 564 582 http://dx.doi.org/10.1108/01437731211253028

Boediharjo. 2002. Kinerja Organisasi. Jakarta: Erlangga.

Daft, Ricahard L. 2011. Era Baru Manajemen. Jakarta: Salemba empat.

Desianty, Sovyia. 2005. Pengarub Gaya Kepemimpinan terhadap komitmen organisasi pada PT POS Indonesia (PERSERO) Semarang. Jurnal Studi Manajemen \& Organisasi Vol.2 No. 1 Januari 2005

Gayatri. 2005. Analisis Pengaruh Prestasi Kerja dan Kompetensi Terbadap Keputusan Promosi Jabatan Karyawan PT. Jasa Angkasa Semesta Tbk., di Jakarta. Jakarta: Jurnal.

Gomes, Faustino Cardoso. 2001. Manajemen Sumber Daya Manusia. Yogyakarta: ANDI OFFSET.

Griffin, Ricky W. 2004. Manajemen. Jakarta: Erlangga.

Hasibuan, Malayu S.P. 2007. Manajemen Dasar, Pengertian dan Masalah. Bumi Jakarta: Aksara.

Hartanto, Frans Mardi. 2009. Paradigma Baru Manajemen Indonesia: Menciptakan Nilai Dengan Bertumpu Pada Kebijakan Dan Potensi Insani. Bandung: Penerbit Mizan.

Hasan, Muhammad Tholchah. 2000. Dinamika Kebidupan Religius, Jakarta: Listafariska Putra.

Khoirusmadi, Ahmad Shofian. 2011. Analisis pengaruh kepemimpinan transformasional terhadap kinerja pegawai dengan budaya organisasi sebagai variabel intervening. Skripsi. Fakultas ekonomi universitas diponegoro.

Luthas, Fred. 2006. Perilaku Organisasi Edisi sepuluh. Yogyakarta: Penerbit ANDI.

Mangkunegara, Anwar Prabu. 2005. Perencanaan dan Pengembangan Sumberdaya Manusia. Bandung: Refika Aditama.

Manullang, M. 2005. Dasar dasar Manajemen. Yogyakarta: Gajah 
Mada University Press.

Mulianto, sindu, Cahyadi eko rudi, widjajakusuma Muhammad Karebet. 2006. Panduan Lengkap Supervisi Diperkaya Perspektif Syariah. Jakarta: Elex Media Komputindo.

Pattiasina, Victor. 2011. Pengaruh Gaya Kepemimpinan Transformasional terhadap Kinerja Pelayanan dengan Budaya kerja dan Penerapan Good Corporate Governance sebagai Variabel Moderasi: Studi pada Rumah Sakit di Kota Ambon. Tesis. Universitas Brawijaya, Malang.

Rofiudin, Agus. 2008. Pengaruh Gaya Kepemimpinan Transformational, Transaksional, Dan Motivasi Kerja Terhadap Kinerja Pegawai Pada Kantor Pelayanan Utama Bea Dan Cukai Tanjung Priok Jakarta. Tesis. Program Pasca Sarjana Universitas Brawijaya. Malang.

Scharf, R. Betty. 1995. Kajian Sosiologi Agama (Terj). Machnun Husein, Yogyakarta: Tiara Wacana.

Setyaningsih, Sri H. 2005. Pengaruh Motivasi Berprestasi dan Gaya Kepemimpinan Camat Terhadap Kinerja Pegawai Pada Kantor Kecamatan Karang Tengah Kota Tangerang Provinsi Banten. Jakarta: Jurnal.

Siagian, Sondang P. 2009. Kiat Meningkatkan Produktivitas Kerja. Jakarta: Rineke Cipta.

Sibili, Nawawi. 2012. Pengarub Gaya Kepemimpinan Transformasional Terhadap Kinerja Karyawan Pada PT Berau Coal Kabupaten Berahu. Jurnal EKSIS Vol.8 No.1, Mar 2012:2001-2181.

Solimun. 2002. Structural Equation Modeling Lisrel dan Amos. Fakultas MIPA Universitas Brawijaya, Malang. Penerbit Universitas Negeri Malang.

Sugiyono, Sugeng, dkk. 1993. "Etos Kerja Wanita Bakul di Kotamadia Yogyakarta dan Kabupaten Sleman" dalam Jurnal Penelitian Agama, Bo, 3. Januari-April 1993.

Sulistyo, Heru. 2010. Pengaruh Kepemimpinan dan Etos Kerja Islami Terhadap Komitmen Karyawan Pada Organisasi dan Kinerja Karyawan PT.Telekomunikasi Indonesia Tbk dan PT. Perusahaan Listrik Negara (persero) Di Provinsi Jawa Tengah 
dan Daerah Istimewa Yogyakarta.Laporan Hasil penelitian, Bidang studi ekonomi islam Universitas Airlangga

Suryo, Bhikkhu Darma. 2010. Pengaruh Gaya Kepemimpinan Transformasional, Budaya Organisasi Dan Inovasi Terhadap Kinerja Studi Pada Panti Asuban Di Kota Tomohon Dan Kabupaten Minahasa. Desertasi FE UB. Jurnal aplikasi manajemen volume 8 nomor 2

Sutono, Fuad Ali Budiman. 2009. Pengarub Kepemimpinan dan Etos Kerja Islami terhadap Kinerja Karyawan di Koperasi Jasa Keuangan Syari'ah Baitul Maal Wat Tamwil di Kecamatan Rembang, Analisis Manajemen Vol. 4 No. 1 Desember 2009.

Tasmara, Toto. 2002. Membudayakan Etos Kerja Islami. Jakarta : Gema Insan Press.

Trito, 2005. Paradikma Baru Manajemen Sumber Daya Manusia. Yogyakarta: Tugu Publiser.

Usman, Husaini. 2008. Manajemen (Teori Praktik dan Riset Pendidikan), Jakarta: Bumi Aksara.

Uyanto, Stanislaus S. 2009. Pedoman Analisis Data dengan SPSS. Yogyakarta: Graha Ilmu

Wahjosumidjo. 1994. Kepemimpinan dan Motivasi. Jakarta: Ghalia Indonesia.

Yousef, Darwish A. 2000. Organizational commitment as a mediator of the relationship between Islamic work ethic and attitudes toward organizational change, Human Relations 2000, Volume 53(4): 513-537:011750. http://hum.sagepub.com/cgi/ content/abstract/53/4/513

Yushak, Mohamed Shamaun and Rajuddin, Adli Rafai Ahmad and Mohamed, Zakiah and Daud, Khairian Mohamad andBawadi, Norfazilah and Sarif, Suhaimi Mhd (2011) Perceived Islamic Work Ethics And Organisational Commitment Among Muslim Engineers In Perak Tengah And Manjung district. In: 2nd International Conference on Engineering Professional Ethics and Education (ICEPEE '11), 17-19 May 2011, Kuala Lumpur. 